ISSN 0258-7122

Bangladesh J. Agril. Res. 35(3) : 387-394, September 2010

\title{
CONSTRAINTS AND STRATEGIES TOWARDS IMPROVING CASSAVA PRODUCTION AND PROCESSING IN ENUGU NORTH AGRICULTURAL ZONE OF ENUGU STATE, NIGERIA
}

\author{
AKINNAGBE O.M. ${ }^{1}$
}

\begin{abstract}
The study was undertaken to ascertain the constraints and strategies towards improving cassava production and processing in Enugu north agricultural zone of Enugu State, Nigeria. Data were collected from 60 cassava producers and processors (farmers) through the use of structured interview schedule. Multistage sampling technique was applied in the selection of respondents. Mean, standard deviation and exploratory factor analysis were used in realizing the objectives. The results showed that the major constraints to cassava production and processing were agronomic factors, technical/institutional factors and financial factors. The major strategies for improving cassava production and processing include making planting material available at the right time in the right places and at reduced prices, establishment of starch based industries in rural areas for processing cassava and formation of farmers' cooperative societies to enhance farmers' access to information and production facilities. The study, therefore, recommended that starch based industries should be established in rural areas for cassava processing in order to encourage both producers and processors for added value. This will also encourage youth in agriculture for economic growth.
\end{abstract}

Keywords: Cassava production and processing, constraints and strategies, Nigeria.

\section{Introduction}

Cassava (Manihot esculenta) is one of the world's most important food crops. In Nigeria, as in most developing countries, it is one of the most important carbohydrate sources. The plant grows to a height of 1 to $3 \mathrm{~m}$ and several roots may be found on each plant. Although cassava leaves are sometimes consumed, the major harvested organ is the tuber, which is actually a swollen root. The plant is propagated mostly from stem cuttings. According to Tonukari (2004), cassava ranks very high among crops that convert the greatest amount of solar energy into soluble carbohydrates per unit of area. Among the starchy staples, cassava gives a carbohydrate production which is about $40 \%$ higher than rice and $25 \%$ more than maize, with the result that cassava is the cheapest source of calories for both human nutrition and animal feeding. A typical composition of the cassava root is moisture (70\%), starch (24\%), fiber (2\%), protein (1\%) and other

${ }^{1}$ Department of Agricultural Extension, University of Nigeria, Nsukka, Enugu State, Nigeria. 
substances including minerals (3\%). A recent study on cassava shows that it accounts for about $70 \%$ of the total calories intake of more than half of the population (Nneoyi, et. al., 2008).

Since past years, cassava production and processing have been facing a lot of problems. Unfortunately, no supply chain structures exist for the commercialization of supplying cassava products as primary source of raw materials for agro-industries. At farm level, the production costs for cassava in Nigeria are high, relative to other countries, production is not oriented towards commercialization, but instead farmers produced and processed cassava as a subsistence crop (Ugwu, 2008). A major limitation of cassava production is the rapid post harvest deterioration of its roots which usually prevents their storage in the fresh state for more than a few days (Okezie and Kosikowski in Tonukari, 2004).

The current trend in cassava production in Nigeria has put a lot of pressure on production of cassava. The Federal Government of Nigeria constituted a presidential initiative on cassava production and export aimed at raising the production level of cassava to 150 million metric tonnes by the end of 2010 . The programme is also expected to assist the country realize an income of US\$5.0 billion per annum from the export of 37.6 million tonnes of dry cassava products such as starch, cassava chips, adhensive and other derivatives. Apart from local demand, there is a high demand for cassava based products in foreign countries. However, the current supply of the cassava may not be able to satisfy foreign market demand (IFAD and FAO, 2005).

Some of the achievements already being recorded by the presidential initiative on cassava production and export were: organization of training workshop at the national centre for agricultural mechanization; development of equipment for the processing of various cassava products targeted for export market in collaboration with International Institute for Tropical Agriculture (IITA); production and distribution of 576,000 bundles of improved cassava cutting by the State Agriculture Development Projects (ADPs) to farmers; production/procurement of planting materials, such as breeds, foundation and certified stocks by the Root and Tuber Expansion Programme Management Unit (RTEPMU), NRCRI, Umudike and JITA; and collaboration with local communities to establish pilot cassava processing centres in each local government area of the cassava producing states for subsequent replication and adoption (Federal Republic of Nigeria, 2008).

In spite these recorded efforts made by different groups and individuals at federal, state and local government levels to increase and improve cassava production and processing in Nigeria. Has proposed increase yields translated into greater incomes of the rural farmers? It therefore becomes important to 
ascertain the factors constraining cassava production and processing in Enugu North Agricultural zone of Enugu State.

\section{Objectives of the study}

The broad objective of the study is to ascertain constraints and strategies towards improving cassava production and processing in Enugu North Agricultural zone of Enugu State, Nigeria. The specific objectives of the study included the following:

1. ascertain constraints towards cassava production and processing; and

2. determine the possible strategies for improving cassava production and processing in the areas.

\section{Methodology}

The study was carried out in Enugu North Agricultural Zone of Enugu State, Nigeria. The zone is one of the three zones in Enugu State. It is situated in the derived savanna climatic belt of Enugu State. The mean temperature falls between $27^{\circ} \mathrm{C}$ and $28^{\circ} \mathrm{C}$ with a prominent climatic season in the area, which include rainy season (April-October) and dry season (November-March). Enugu North Agricultural Zone covers an estimated population of about 895,113 persons (National Population Commission, 2006)

Multistage random sampling technique was employed in the selection of respondents for the study. In the first stage, three Local Government Areas (LGAs); namely Nsukka, Udenu and Uzo-uwani, out of the seven (Isi-uzo, Igbo Etiti, Uzo-uwani, Nsukka, Udenu, Igbo-Eze North and Igbo-Eze South) LGAs in the zone were randomly selected, using simple random sampling technique. Secondly, two communities out of the list of five communities provided by the community leaders in the communities were randomly selected from each of the 3 LGAs, making a total of six communities. The third stage involved the selection of individual respondents. Ten cassava farmers who were involved in both cassava production and processing were purposely selected and interviewed for the study from each of the six communities selected. This is because, in the study area, the producers are also the processors. Thus, a total of 60 cassava producers and processors constituted the population size for the study. Data for the study were collected from the respondents through the use of interview schedule.

Exploratory factor analysis procedure using the principal factor model with varimax rotation was employed in grouping the constraint variables into major constraint factors. In factor analysis, the factor loading under each constraint (beta weight) represent a correlation of variables (constant area) to the identified constraint factor and has the same interpretation as any correlation coefficient. 
However, only variables with loading of 0.40 and above (10\% overlapping variance (Camrey, in Chukwuone, Agwu, and Ozor, 2006) were used in naming the factors.

In trying to obtain possible strategies towards improving cassava production and processing, a 3 point Likert-type scale with three response options (3 Very effective; 2 = Effective; and 1 = Not effective) was used. The values on the Likert-type scale were summated to 6 , which were later divided by 3 , to get a mean score of 2.0. Then respondents' mean scores were obtained for each response item such that any one higher or equal to 2.0 was regarded as a possible strategy.

Mean, standard deviation, and factor analysis were used for data analysis. The SPSS constituted the software package used for the analysis.

\section{Results and Discussion}

\section{Factors militating against cassava production and processing}

Exploratory factor analysis was used to group the variables into possible constraint factors for policy relevance. The result of the rotated component matrix showing the extracted factors, based on the response of cassava producers/processors on factor militating against cassava production and processing is shown in Table 1. Three constraint factors were extracted based on the response of the respondents. Only variables with loadings of 0.40 and above (10\% overlapping variance) were used in naming the factors. Factors 1,2 , and 3 were named agronomic, technical/institutional and financial problem, respectively.

Agronomic factor was dominated by weed problem (0.48), high incidence of pest and diseases (0.72), unavailability of agro chemicals and other insecticides (0.68), soil erosion problem (0.78) and soil fertility problem (0.91). The loadings under technical/institutional problems include the following: scarcity of planting materials (0.48), high cost of improved varieties (0.76), limited processing option (0.82), instability in government policy (0.49), difficulties of harvesting during dry season (-0.79), lack of adequate technical knowledge of modern processing technique $(0.81)$ and poor access road for transportation of farm procedure (0.68).

Specific issues with high loading under financial factor include lack of finance (0.79), difficulties in obtaining credit facility (0.69), lack of collateral required to secure loan (0.71), high cost of inorganic fertilizer (0.69), high cost of agro chemicals $(-0.55)$, lack of modern processing equipment $(0.73)$ and high cost of processing (0.65). 
Table 1. Rotated component matrix based on the responses of farmers/processor on possible constraints to cassava production and processing.

\begin{tabular}{|c|c|c|c|}
\hline \multirow{2}{*}{ Possible Constraints } & \multicolumn{3}{|c|}{ Factors } \\
\hline & 1 & 2 & 3 \\
\hline Lack of finance & 0.38 & -0.05 & 0.75 \\
\hline Scarcity of planting materials & 0.39 & 0.48 & 0.14 \\
\hline Difficulty in obtaining credit facilities & 0.38 & 0.31 & 0.69 \\
\hline Scarcity of farm land & 0.48 & 0.69 & -0.30 \\
\hline $\begin{array}{l}\text { Lack of technical knowledge in the use of improved } \\
\text { technology }\end{array}$ & 0.77 & 0.41 & 0.05 \\
\hline High cost of improved varieties & 0.07 & 0.76 & -0.26 \\
\hline High interest rate on loan & 0.59 & 0.42 & -0.48 \\
\hline Low soil fertility & -0.72 & 0.55 & 0.15 \\
\hline Lack of collateral required to secure loan & 0.12 & 0.05 & 0.71 \\
\hline Limited processing option & 0.06 & 0.82 & -0.09 \\
\hline Poor access roads for transportation of farm procedure & 0.38 & 0.68 & 0.21 \\
\hline Weed problem & 0.67 & -0.08 & 0.24 \\
\hline High incidence of pests and diseases infestations & 0.72 & 0.17 & -0.14 \\
\hline High cost of inorganic fertilizer & 0.29 & 0.18 & -0.69 \\
\hline Unavailability of organic fertilizer & 0.16 & 0.41 & -0.60 \\
\hline Unavailability of agro-chemicals and other equipment & 0.68 & -0.02 & 0.16 \\
\hline High cost of agro-chemicals & -0.09 & 0.06 & -0.55 \\
\hline Difficulties of harvesting during dry season & 0.08 & -0.79 & -0.17 \\
\hline $\begin{array}{l}\text { Unavailability of labour to carry out essential farming } \\
\text { activities }\end{array}$ & 0.42 & -0.62 & 0.32 \\
\hline Poor extension agent farmers contact & 0.64 & -0.12 & 0.51 \\
\hline Instability in government policy & -0.04 & 0.49 & 0.08 \\
\hline $\begin{array}{l}\text { Lack of adequate technical knowledge in the use of } \\
\text { improved technologies }\end{array}$ & 0.29 & 0.81 & 0.15 \\
\hline Marketing problems & 0.28 & 0.68 & 0.36 \\
\hline Soil erosion problem & 0.78 & -0.03 & 0.24 \\
\hline $\begin{array}{l}\text { Lack of market, roads and social facilities like hospitals, } \\
\text { water and schools }\end{array}$ & 0.52 & 0.44 & -0.19 \\
\hline Poor access to good road in transporting cassava product & -0.01 & 0.20 & -0.02 \\
\hline High cost of hired labour & 0.20 & -0.06 & -0.82 \\
\hline Lack of modem processing equipment & -0.07 & -0.02 & 0.73 \\
\hline High cost of processing & 0.19 & -0.03 & 0.65 \\
\hline Soil fertility problem & 0.91 & -0.12 & -0.09 \\
\hline
\end{tabular}

Note: Factors: l=Agronomic problem; 2=Technical/Institutional problem; 3=Financial problem

Extraction Method: Principal Component Analysis

Rotation Method: Varimax with Kaiser Normalization 


\section{Possible strategies of improving cassava production and processing}

Table 2 shows the perceived strategies of improving cassava production and processing in the study areas. According to the respondents, (cassava producers and processors), the best perceived strategies include: making planting material available to farmers at the right time in the right quantity $(\bar{x}=2.63)$; Establishment of starch based industries in rural areas for processing cassava ( $\bar{X}$ = 2.63); proper and regular weeding of cassava farm $(\bar{x}=2.50)$ and subsidizing the prices of agricultural inputs used in production and processing of cassava ( $\bar{x}$ 2.48). Availability of inputs at the right time and in the right place is an important factor that enhances adoption of technology and when this is available, the price could be subsidized to enable farmers to be able to purchase them, this will always take care of weeding in cassava farm by the use of herbicides.

Table 2. Mean and standard deviations on possible strategies of improving cassava production and processing.

\begin{tabular}{|c|c|c|}
\hline Strategies & Mean score & Std. deviation \\
\hline $\begin{array}{l}\text { Formation of cooperatives society to enhance farmers’ } \\
\text { access to finance }\end{array}$ & $2.37 *$ & 0.88 \\
\hline Providing machineries for production and processing & $2.25^{*}$ & 0.77 \\
\hline Subsidizing the prices of agricultural inputs & $2.48^{*}$ & 0.74 \\
\hline $\begin{array}{l}\text { Making planting material available to farmer' at the right } \\
\text { time in the right quantity }\end{array}$ & 2.63* & 0.73 \\
\hline Procurement of fertilizer & $2.22 *$ & 0.55 \\
\hline Using of resistant and high yielding varieties & $2.28^{*}$ & 0.81 \\
\hline Creating credit facilities & $2.25 *$ & 0.81 \\
\hline Making interest rate low & $2.32 *$ & 0.83 \\
\hline $\begin{array}{l}\text { Establishment of starch based industries in rural areas for } \\
\text { processing cassava }\end{array}$ & $2.62 *$ & 0.72 \\
\hline Planting sweet types which has a relatively low cyanide & 1.93 & 0.58 \\
\hline $\begin{array}{l}\text { Creating market, roads and social facilities like hospitals, } \\
\text { water and schools }\end{array}$ & $2.15 *$ & 0.57 \\
\hline Use of recommended spacing and planting at the right time & $2.23^{*}$ & 0.90 \\
\hline Proper and regular weeding of cassava farms & $2.50^{*}$ & 0.65 \\
\hline $\begin{array}{l}\text { Regular visit by extension agents for regular and proper } \\
\text { extension delivery system }\end{array}$ & $2.45^{*}$ & 0.76 \\
\hline $\begin{array}{l}\text { Sustaining the input supplies e.g fertilizer, labour } \\
\text { availability and structured market. }\end{array}$ & $2.42 *$ & 0.86 \\
\hline
\end{tabular}

* Perceived strategies

Other perceived strategies include regular visit by extension agents for regular and proper extension delivery system $(\bar{x}=2.45)$, availability of labour 
and market facilities $(\bar{x}=2.42)$, formation of cooperatives society to enhances farmers access to finance ( $\bar{x}$ 2.37), using of resistant and high yielding varieties ( $\bar{x}=2.28)$, and creating credit facilities $(\bar{x}=2.5)$, providing machineries for production and processing $(\bar{x}=2.23$ ), use of recommended spacing and planting at the right time $(\bar{x}=2.22)$, creating market, roads and social facilities like hospital, water and schools $(\bar{x}=2.15)$.

\section{Conclusion and Recommendations}

The study ascertained the perception of the farmers/processor on constraints and strategies towards improving cassava production and processing in Enugu North Agricultural zone of Enugu State, Nigeria. The result showed that the major constraints to cassava production and processing were agronomic factor (weed problem, high incidence of pest and diseases, unavailability of agro-chemicals and other insecticides, soil erosion problem and soil fertility problem); technical/institutional problems (scarcity of planting materials, high cost of improved varieties, limited processing option, instability in government policy, difficulties of harvesting during dry season, lack of adequate technical knowledge of modern processing technique and poor access road for transportation of farm procedure) and financial factor (lack of finance, difficulties in obtaining credit facility, lack of collateral required to secure loan, high cost of inorganic fertilizer, high cost of agro chemicals, lack of modern processing equipment and high cost of processing).

Continuing strong growth in food demand for cassava reflects the important role that cassava plays in the diets. Farmers should be encouraged and assisted by agricultural extension agents and local leaders in the rural areas to join or set up groups or organization. This will enable the farmers / processors to have access to timely funds and materials needed for production and processing. Policy should encourage establishment of starch based industries in rural areas. This will go a long way in reducing food insecurity in the country.

\section{References}

Chukwuone, N.A. A.E. Agwu and N. Ozor. 2006. Constraints and Strategies Towards Effective Cost-sharing of Agricultural Technology Delivery in Nigeria: Perception of Farmers and Agricultural Extension Personnel. Journal of International Agricultural and Extension Education. 13(1). pp. 29-40.

Federal Republic of Nigeria. 2006. National Report on International Conference On Agrarian Reform and Rural Development held at Porto Alegre, 7 -10 March 2006. pp. 1-22.

IFAD and FAO. 2005. A Review of Cassava in Africa with Country Case Studies on Nigeria, Ghana, the United Republic of Tanzania, Uganda and Benin. 
Proceedings of the Validation Forum on the Global Cassava Development Strategy. Volume 2. FAO, Rome, 2005.

National Population Commission. 2006. Nigeria Population Figure. National Population Commission, Abuja.

Nneoyi, I.O., M.N. Henry, A.M.Walter and E.E. Ebingha. 2008. Group Dynamics and Technology Use among Female Cassava Farmers in Akpabuyo Local Government Area, Cross River State, Nigeria. Agricultural Journal. 3 (4): 292-298.

Tonukari, N.J. 2004. Cassava and the future of starch. Electronic Journal of Biotechnology. Vol. 7 No.1. Issue of April 15.

Ugwu, C.C. 2008. Gender Roles in Cassava Production and Processing in Enugu North Agricultural Zone of Enugu State, Nigeria. B. Agric Thesis, Department of Agricultural Extension, University of Nigeria, Nsukka. 